Pak. j. sci. ind. res. Ser. B: biol. sci. 201457 (2) 59-65

\title{
Estimating Combining Ability of Yield and its Components in Upland Cotton Through Line $\times$ Tester Analysis
}

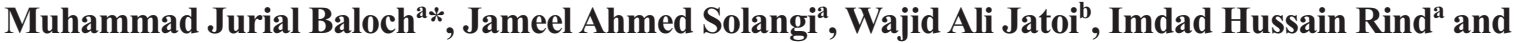 \\ Nasreen Fatima Veesar ${ }^{\mathrm{a}}$ \\ ${ }^{a}$ Department of Plant Breeding and Genetics, Sindh Agriculture University Tandojam, Sindh, Pakistan \\ ${ }^{\mathrm{b}}$ Cotton Section, Agriculture Research Institute, Tandojam, Sindh, Pakistan
}

(received November 4, 2013; revised March 4, 2014; accepted March 10, 2014)

\begin{abstract}
Combining ability estimates are very important genetic attributes to cotton breeders in predicting improvement that could be envisaged from hybridisation and selection programmes. The crosses were attempted in a line $\times$ tester mating design, which involved five female and three testers, hence $15 \mathrm{~F}_{1}$ hybrids were developed. The experiment was carried out in a randomised complete block design with four replications. The mean squares due to general combining ability (GCA) of lines and testers and specific combining ability (SCA) of lines $\times$ testers interactions were significant, for all the characters studied. The significance of GCA and SCA variances suggests that both additive and non-additive genes were controlling the characters, yet additive genes of female lines were predominant because their variances were generally, higher than GCA of testers and SCA of lines $\times$ testers. Among the lines, parents CIM-506, CRIS-134 and Sadori and from testers, Bt-cotton and Sindh-1 exhibited higher GCA effects hence proved to be the best general combiners for most of the traits studied. Results further suggested that these potential parents can reliably be used in hybridisation and selection programmes for extracting desirable plants from segregating populations. The $\mathrm{F}_{1}$ hybrids like Sadori $\times$ Sindh-1, Chandi $\times$ Bt-cotton and Sadori $\times$ BH-160 were best specific combiners for earliness (bolls formation and opening at 90 and 120 days after planting), bolls per plant, boll weight, seed cotton yield per plant, lint $\%$ and staple length. The performance of $\mathrm{F}_{1}$ hybrids per $s e$ was very well reflected in SCA effects, conferring the potentiality of $\mathrm{F}_{1}$ hybrids.
\end{abstract}

Keywords: combining ability, hybridisation, genetic variability, upland cotton

\section{Introduction}

For the improvement of any plant character, plant breeders heavily rely upon the availability of genetic variability determined by various mating designs. Cotton breeders are well aware of the phenomenon that in a hybridisation programme, certain crosses pass-on more favourable genes towards the progeny than the others. Thus, some cross combinations may be superior as compared to their parents for improving economic traits in cotton breeding programmes.

Cotton breeders are looking for desirable genes and gene complexes, thus identification of promising parents/ individuals is very important task in all breeding programmes (Baloch et al., 2010). Mating designs are one of the biometrical breeding tools which help the breeders to recognise the potential parents and the promising recombinants/hybrids. For these purposes, diallel analysis has been extensively used but line $\times$ tester analysis is still superior mating design against diallel in that, it

*Author for correspondence; E-mail: j.rind58@gmail.com uses more and different sets of parents as males and females with relatively small number of crosses. Thus, it provides more reliable estimates of genetic variances among males and females as compared to diallel analysis. In a diallel mating, the parents are crossed in all possible combinations to identify parents as best or /poor general combiners through general and specific cross combinations. It involves both direct as well as reciprocal crosses through which maternal effects can also be ascertained. To exploit different types of gene action in plant population, information regarding the relative magnitude of genetic variation and combining ability for important traits in cotton is essential. The first step in the utilisation of heterosis is a selection from the available germplasm that could produce the best combinations of important characters. The entire genetic variability in the analysis of each trait is partitioned into general and specific combining ability as defined by Sprague and Tatum (1942), and reciprocal effects as sketched by Griffing (1956). They stated that GCA effects administer the additive type of gene action, 
whereas, SCA effects are due to genes which are nonadditive (dominant or epistatic) in nature. Batool and Khan (2012), Hassan et al. (1999), and Sayal et al. (1997), reported the importance of non-additive type of gene action for different cotton traits. However, Khan (2010), Bhutto et al. (2001), Baloch et al. (2000), and Khan et al. (1991), stressed upon the appreciable degree of variance due to GCA for morpho-yield traits. Makhdoom (2011), Khan et al. (2009; 2005), and Khan (2003), observed that mean squares due to GCA and SCA were highly significant; however, the genetic variances due to SCA were greater than GCA for yield related traits, showing the predominance of non-additive gene action. High $\times$ low and low $\times$ high GCA parents performed well in SCA determination (Makhdoom, 2011). Many commercial cotton cultivars despite their high or low agronomic performance combine in a better or poor way when used as a parental cultivars in cross combinations (Batool et al., 2010, Makhdoom et al., 2010). Therefore, the present research work was conducted to evaluate the performance of some new but important commercial upland cotton genotypes and $15 \mathrm{~F}_{1}$ hybrids were developed through line $\times$ tester analysis so as to ascertain their genetic potential, genetic variability and combining ability for seed cotton yield and yield related traits.

\section{Materials and Methods}

An experiment was conducted at the experimental field of the Department of Plant Breeding and Genetics, Sindh Agriculture University Tandojam, Pakistan, during 2010. The experimental material was consisted of 5 parental female lines (CIM-506, CRIS-134, CIM-496, Sadori and Chandi) and 3 testers/pollinators (Bt-cotton, Sindh-1 and BH-160) and their $15 F_{1}$ hybrids belonging to upland cotton (Gossypium hirsutum L.). The seed of $15 \mathrm{~F}_{1}$ hybrids was developed by attempting crosses in line $\times$ tester mating fashion during 2009. The seed of parents and their $F_{1}$ hybrids was sown in a randomised complete block design with four replications. Distance between row to row and plant to plant was kept at 75.0 and $30 \mathrm{~cm}$, respectively. Three rows of each genotype were grown in a plot size of $7.5 \times 45.0$ feet. Sowing was done by dibbling method. Three seeds per hill were sown to ensure uniform stand. After 25 days of sowing, seedlings were thinned and only one vigorous plant was allowed to grow. The inorganic fertiliser like one bag $(50 \mathrm{~kg})$ of DAP per hectare was applied at the time of sowing, whereas, two bags of urea, one with third irrigation and second dose was applied at the time of grain formation. To reduce the intensity of harmful weeds, weedicide like Buctrol Super at the rate of $1000 \mathrm{cc}$ was applied after first irrigation. Five plants from each replication per genotype were tagged at random from central rows excluding border plants for recording the data.

The characters studied were; node number to set first sympodial branch, bolls formed at 90 days after planting, bolls opened at 120 days after planting, plant height $(\mathrm{cm})$, bolls per plant, boll weight $(\mathrm{g})$, seed cotton yield per plant $(\mathrm{g})$ ginning outturn percentage (GOT\%) and staple length $(\mathrm{mm})$. The analysis of variance was carriedout according to Gomez and Gomez (1984) for determining differences among the genotypes whereas, combining ability variances and effects were calculated according to statistical methods developed by Kempthorne (1957) and adopted by Singh and Choudhry (1985).

\section{Results and Discussion}

The mean squares from analysis of variance (Table 1) revealed significant differences for GCA of lines, GCA of testers and SCA of lines $\times$ testers indicating predominance of additive as well as non-additive genes controlling node number to first sympodial branch, bolls formed at 90 days after planting (DAP), bolls opened at 120 (DAP), plant height (cm), bolls per plant, boll weight $(\mathrm{g})$, seed cotton yield per plant $(\mathrm{g})$ ginning outturn percentage (GOT\%) and staple length $(\mathrm{mm})$. The mean performance of hybrids per se summarised in Table 2 indicates that CRIS-134 $\times$ Sindh-1 produced maximum bolls per plant, gave tallest plants, yet ranked next in GOT\% and staple length. While, hybrid Sadori $\times$ Bt-cotton formed maximum bolls at 90 days after planting (DAP), yet ranked next good performing in bolls opened at 120 (DAP), boll weight and seed cotton yield per plant. The hybrid Chandi $\times$ Bt-cotton opened maximum bolls at 120 (DAP); CIM-496 $\times$ Bt-cotton recorded heavier bolls; Sadori $\times$ Sindh- 1 produced maximum seed cotton yield per plant and scored next in bolls per plant; CRIS-134 × BH-160 ginned maximum GOT\% and CRIS-134 $\times$ Bt-cotton measured longest staple. Among the parents, Chandi formed lowest node to $1^{\text {st }}$ sympodial branch, opened maximum bolls after 120 (DAP), whereas, Sadori formed maximum bolls at 90 (DAP) and measured tallest plants, weighed bigger bolls, produced maximum seed cotton yield and ginned highest GOT\% and ranked second in bolls per plant and staple length, while, CRIS-134 produced maximum bolls per plant and measured longest staple length. 
Table 1. Mean squares from line $\times$ tester analysis for various characters in upland cotton

\begin{tabular}{|c|c|c|c|c|c|c|c|c|c|c|}
\hline $\begin{array}{l}\text { Source of } \\
\text { variation }\end{array}$ & DF & $\begin{array}{l}\text { Node } \\
\text { number } \\
\text { to } 1^{\text {st }} \\
\text { sympodia }\end{array}$ & $\begin{array}{l}\text { Earliness } \\
\text { (bolls } \\
\text { formed at } \\
90 \mathrm{DAP}^{*} \text { ) }\end{array}$ & $\begin{array}{l}\begin{array}{l}\text { Earliness } \\
\text { (bolls }\end{array} \\
\text { opened at } \\
120 \text { DAP) }\end{array}$ & $\begin{array}{l}\text { Plant } \\
\text { height }\end{array}$ & $\begin{array}{l}\text { No. of } \\
\text { bolls per } \\
\text { plant }\end{array}$ & Boll weight & $\begin{array}{l}\text { Seed } \\
\text { cotton } \\
\text { yield per } \\
\text { plant }\end{array}$ & GOT \% & $\begin{array}{l}\text { Staple } \\
\text { length }\end{array}$ \\
\hline Replications & 3 & 0.36 & 0.77 & 0.90 & 137.90 & 3.49 & 0.03 & 6.00 & 1.59 & 0.27 \\
\hline Genotypes & 22 & $4.63 * *$ & $61.63 * *$ & $43.05 * *$ & $617.30 * *$ & $236.10^{* *}$ & $0.65 * *$ & $4763.00 * *$ & $10.12 * *$ & $3.87 * *$ \\
\hline Crosses & 14 & $5.59 * *$ & $50.07 * *$ & $37.20 * *$ & $590.70 * *$ & $3.81 * *$ & $0.83 * *$ & $3176.00 * *$ & $12.03 * *$ & $4.16^{* *}$ \\
\hline Lines (GCA) & 4 & $3.00 * *$ & $70.15 * *$ & $41.85 * *$ & $1045.00 * *$ & $5.91 * *$ & $0.79 * *$ & $4279.00 * *$ & $27.89 * *$ & $8.22 * *$ \\
\hline Testers (GCA) & 2 & $10.22 * *$ & $12.22 * *$ & $11.48 * *$ & $952.30 * *$ & $1.79 * *$ & $2.07 * *$ & $3611.00 * *$ & $2.45 * *$ & $0.02 \mathrm{~ns}$ \\
\hline $\begin{array}{l}\text { Lines } \times \text { tester } \\
(\mathrm{SCA})\end{array}$ & 8 & $5.73 * *$ & $49.49 * *$ & $41.30^{* *}$ & $273.20 * *$ & $3.26^{* *}$ & $0.53 * *$ & $2515.00 * *$ & $6.49 * *$ & $3.16^{* *}$ \\
\hline Error & 42 & 0.76 & 0.62 & 0.56 & 12.14 & 0.43 & 0.01 & 67.86 & 0.41 & 0.58 \\
\hline
\end{tabular}

$* *=$ significant at $1 \%$ probability level, DAP * = days after planting.

Table 2. Average performance of eight parents and their fifteen $F_{1}$ hybrids for various characters in upland cotton

\begin{tabular}{|c|c|c|c|c|c|c|c|c|c|}
\hline Parents (lines and testers) & $\begin{array}{l}\text { Node } \\
\text { to } 1^{\text {st }} \\
\text { sympodia }\end{array}$ & $\begin{array}{l}\text { Bolls } \\
\text { formed at } \\
90 \text { DAP* }\end{array}$ & $\begin{array}{l}\text { Bolls } \\
\text { opened at } \\
120 \text { DAP }\end{array}$ & $\begin{array}{l}\text { Plant } \\
\text { height } \\
(\mathrm{cm})\end{array}$ & $\begin{array}{l}\text { Bolls per } \\
\text { plant }\end{array}$ & $\begin{array}{l}\text { Boll weight } \\
\text { (g) }\end{array}$ & $\begin{array}{l}\text { Seed cotton } \\
\text { yield per } \\
\text { plant }(\mathrm{g})\end{array}$ & $\begin{array}{l}\text { GOT } \\
(\%)\end{array}$ & $\begin{array}{l}\text { Staple } \\
\text { length } \\
(\mathrm{mm})\end{array}$ \\
\hline CIM-506 & 6.50 & 7.50 & 6.25 & 134.50 & 51.00 & 3.25 & 165.80 & 37.75 & 27.50 \\
\hline CRIS-134 & 5.75 & 6.25 & 5.00 & 140.50 & 54.50 & 3.15 & 171.70 & 37.75 & 28.50 \\
\hline CIM-496 & 7.50 & 8.50 & 7.50 & 115.00 & 49.50 & 3.45 & 170.80 & 36.75 & 28.25 \\
\hline Sadori & 5.50 & 9.75 & 6.75 & 146.50 & 53.50 & 4.05 & 216.65 & 39.25 & 28.25 \\
\hline Chandi & 5.50 & 4.50 & 9.75 & 139.50 & 52.50 & 3.25 & 167.50 & 37.50 & 27.50 \\
\hline Bt-cotton & 7.50 & 7.75 & 6.50 & 121.00 & 50.00 & 3.55 & 177.50 & 36.25 & 27.25 \\
\hline Sindh-1 & 5.50 & 6.50 & 4.50 & 118.25 & 48.00 & 3.10 & 148.80 & 37.50 & 28.25 \\
\hline BH-160 & 7.00 & 6.50 & 6.25 & 138.50 & 46.50 & 3.30 & 153.50 & 38.50 & 26.50 \\
\hline \multicolumn{10}{|l|}{$F_{1}$ hybrids } \\
\hline CIM-506 $\times$ Bt-cotton & 7.50 & 9.50 & 7.75 & 140.00 & 60.50 & 3.10 & 187.60 & 38.25 & 29.25 \\
\hline CIM-506 × Sindh-1 & 5.25 & 11.50 & 9.75 & 145.00 & 58.50 & 2.95 & 202.05 & 36.25 & 28.50 \\
\hline CIM-506 × BH-160 & 4.50 & 12.00 & 11.00 & 153.75 & 63.50 & 3.30 & 209.45 & 39.50 & 29.00 \\
\hline CRIS-134 $\times$ Bt-cotton & 6.75 & 7.75 & 5.75 & 132.75 & 65.50 & 3.65 & 239.05 & 40.25 & 30.25 \\
\hline CRIS-134 × Sindh-1 & 8.50 & 12.50 & 9.00 & 163.75 & 70.50 & 3.05 & 215.00 & 41.25 & 30.00 \\
\hline CRIS-134 × BH-160 & 5.75 & 9.50 & 7.75 & 153.75 & 66.50 & 3.45 & 229.45 & 41.50 & 28.50 \\
\hline CIM-496 $\times$ Bt-cotton & 6.50 & 9.50 & 7.25 & 143.75 & 57.00 & 4.55 & 259.30 & 38.25 & 27.75 \\
\hline CIM-496 × Sindh-1 & 7.50 & 11.75 & 9.75 & 153.75 & 60.50 & 3.55 & 214.80 & 37.50 & 29.50 \\
\hline CIM-496 × BH-160 & 5.50 & 14.75 & 11.50 & 130.00 & 66.50 & 3.15 & 209.50 & 37.00 & 28.75 \\
\hline Sadori $\times$ Bt-cotton & 7.75 & 16.25 & 12.50 & 124.50 & 64.50 & 4.05 & 261.20 & 40.25 & 27.50 \\
\hline Sadori $\times$ Sindh -1 & 7.00 & 15.00 & 11.00 & 137.50 & 68.50 & 3.85 & 263.75 & 41.00 & 28.25 \\
\hline Sadori $\times$ BH-160 & 5.75 & 16.00 & 12.50 & 133.75 & 66.50 & 3.00 & 199.50 & 38.50 & 29.25 \\
\hline Chandi $\times$ Bt-cotton & 5.25 & 11.00 & 15.50 & 123.75 & 66.50 & 3.65 & 242.75 & 39.25 & 28.00 \\
\hline Chandi $\times$ Sindh -1 & 7.75 & 10.20 & 11.50 & 133.75 & 67.50 & 3.10 & 209.20 & 3725 & 26.50 \\
\hline Chandi $\times$ BH-160 & 7.50 & 10.00 & 7.50 & 127.50 & 59.50 & 3.10 & 184.40 & 36.50 & 27.50 \\
\hline $\mathrm{LSD} /(5 \%)$ & 2.16 & 9.50 & 1.84 & 8.73 & 1.63 & 0.24 & 20.66 & 1.59 & 2.16 \\
\hline
\end{tabular}

DAP* = days after planting.

The mean squares due to GCA of lines were highly significant for all the characters (Table 1), whereas, GCA effects among the lines revealed that CRIS-134 displayed maximum GCA for number of bolls per plant, plant height, GOT \% and staple length (1.02) and Sadori exhibited maximum GCA effects for bolls formed at 90 days, bolls opened at 120 days and seed cotton yield per plant; CIM-496 recorded higher GCA effects for boll weight and moderately desirable for plant height, yet CIM-506 expressed negative but desirable GCA effect for $1^{\text {st }}$ sympodial node number (Table 3 ).
From the tester parents, Sindh-1 demonstrated higher GCA effects for node number to set first sympodial branch, bolls formed at 90 days of planting, bolls opened at 120 days after planting and total number of bolls formed. While, tester Bt-cotton recorded maximum GCA effects for boll weight, seed cotton yield per plant and GOT\% (Table 3).

Whereas, BH-160 exhibited maximum GCA for staple length, yet it expressed maximum but negatively desirable GCA for node number to $1^{\text {st }}$ sympodial branch (Table 3). 
With respect to SCA effects, hybrid Sadori $\times$ Sindh-1 recorded maximum SCA estimates for bolls per plant, boll weight, seed cotton yield per plant and GOT \%. Hybrid Chandi $\times$ Bt-cotton exhibited maximum SCA for bolls formed at 90 days after planting and bolls opened at 120 days after planting; Sadori $\times$ BH-160 measured longer staple length and also gave negatively desirable SCA effect for $1^{\text {st }}$ sympodial node number (Table 4).

The analysis of variance showed highly significant differences among the genotypes (eight parents and fifteen $\mathrm{F}_{1}$ hybrids) for all the traits (Table 1). The partition of crosses mean squares into GCA for lines, GCA for testers and SVA for lines $\times$ tester interaction also revealed significant differences for all traits except that the staple length in tester was non-significant. These results indicate that both additive and non-additive genes were operating for the studied traits. While, comparing the mean squares of lines and testers, the results indicated that lines showed greater GCA variances for majority of the traits against the testers (Lu and Myers, 2011; Khanzada et al., 2008; Panhwar et al., 2008). When the SCA of lines $\times$ testers interaction was compared with GCA of lines or testers, it was noted that GCAs of lines specially were higher

Table 3. General combining ability (GCA) effects of lines and testers for various characters in upland cotton

\begin{tabular}{|c|c|c|c|c|c|c|c|c|c|}
\hline Parents & $\begin{array}{l}\text { Node } \\
\text { number } \\
\text { to } 1^{\text {st }} \\
\text { sympodia }\end{array}$ & $\begin{array}{l}\text { Earliness } \\
\text { (bolls } \\
\text { formed at } \\
90 \mathrm{DAP}^{*} \text { ) }\end{array}$ & $\begin{array}{l}\text { Earliness } \\
\text { (bolls opened } \\
\text { at } 120 \text { DAP) }\end{array}$ & $\begin{array}{l}\text { Plant } \\
\text { height }\end{array}$ & $\begin{array}{l}\text { No. of } \\
\text { bolls } \\
\text { per } \\
\text { plant }\end{array}$ & $\begin{array}{l}\text { Boll } \\
\text { weight }\end{array}$ & $\begin{array}{l}\text { Seed } \\
\text { cotton } \\
\text { yield per } \\
\text { plant }\end{array}$ & GOT \% & $\begin{array}{l}\text { Staple } \\
\text { length }\end{array}$ \\
\hline \multicolumn{10}{|c|}{ Lines (females) } \\
\hline CIM-506 & -0.83 & -1.54 & -0.68 & 6.44 & -0.83 & -0.32 & -23.76 & -0.85 & 0.35 \\
\hline CRIS-134 & 0.42 & -2.21 & -1.93 & 10.27 & 0.84 & -0.05 & 4.37 & 2.15 & 1.02 \\
\hline CIM-496 & -0.08 & -1.21 & -1.18 & 2.69 & -0.70 & 0.32 & 4.40 & -1.27 & 0.10 \\
\hline Sadori & 0.25 & 3.54 & 2.65 & -7.90 & 0.59 & 0.20 & 26.34 & 1.06 & -1.23 \\
\hline Chandi & 0.25 & 1.45 & 1.15 & -11.48 & 0.09 & -0.15 & -11.35 & -1.10 & -0.01 \\
\hline S.E.(gi.) & 0.25 & 0.22 & 0.21 & 1.00 & 0.18 & 0.02 & 2.37 & 0.18 & 0.21 \\
\hline \multicolumn{10}{|c|}{ Testers (pollinators/males) } \\
\hline Bt-cotton & 0.17 & -0.71 & -0.53 & -6.86 & -0.33 & 0.37 & 14.52 & 0.40 & -0.01 \\
\hline Sindh-1 & 0.62 & 0.84 & 0.87 & 6.94 & 0.24 & -0.13 & -2.50 & -0.15 & -0.01 \\
\hline BH-160 & -0.78 & -0.11 & -0.33 & -0.06 & 0.10 & -0.23 & -12.00 & -0.25 & 0.04 \\
\hline S.E. (gi.) & 0.19 & 0.17 & 0.16 & 0.77 & 0.14 & 0.02 & 1.84 & 0.14 & 0.17 \\
\hline
\end{tabular}

DAP* $=$ days after planting.

Table 4. Specific combining ability (SCA) estimates from line $\times$ tester analysis for various characters in upland cotton

\begin{tabular}{|c|c|c|c|c|c|c|c|c|c|}
\hline $\mathrm{F}_{1}$ Hybrids & $\begin{array}{l}\text { Node } \\
\text { number } \\
\text { to } 1^{\text {st }} \\
\text { sympodia }\end{array}$ & $\begin{array}{l}\text { Earliness } \\
\text { (bolls } \\
\text { formed at } \\
90 \mathrm{DAP}^{*} \text { ) }\end{array}$ & $\begin{array}{l}\text { Earliness } \\
\text { (bolls opened } \\
\text { at } 120 \text { DAP) }\end{array}$ & $\begin{array}{l}\text { Plant } \\
\text { height }\end{array}$ & $\begin{array}{l}\text { No. of } \\
\text { bolls per } \\
\text { plant }\end{array}$ & $\begin{array}{l}\text { Boll } \\
\text { weight }\end{array}$ & $\begin{array}{l}\text { Seed } \\
\text { cotton } \\
\text { yield per } \\
\text { plant }\end{array}$ & $\begin{array}{l}\text { GOT } \\
\%\end{array}$ & $\begin{array}{l}\text { Staple } \\
\text { length }\end{array}$ \\
\hline CIM-506 × Bt-cotton & 1.58 & -1.46 & -1.72 & 0.61 & 45.63 & -0.38 & -26.62 & -0.15 & 0.35 \\
\hline CIM-506 $\times$ Sindh-1 & -1.12 & -1.01 & -1.12 & -8.19 & 43.06 & -0.03 & 4.85 & -1.60 & -0.40 \\
\hline CIM-506 × BH-160 & -0.47 & 2.44 & 2.83 & 7.56 & 48.20 & 0.42 & 21.75 & 1.75 & 0.05 \\
\hline CRIS-134 $\times$ Bt-cotton & -0.42 & -2.54 & -2.47 & -10.47 & 48.96 & -3.10 & -3.30 & -1.15 & 0.68 \\
\hline CRIS-134 × Sindh-1 & 0.88 & 3.91 & 3.13 & 6.73 & 53.39 & -0.20 & -10.33 & 0.40 & 0.43 \\
\hline CRIS-134 × BH-160 & -0.47 & -1.39 & -0.67 & 3.73 & 49.53 & 0.30 & 13.62 & 0.75 & -1.12 \\
\hline CIM-496 × Bt-cotton & -0.17 & -1.79 & -1.72 & 8.11 & 42.00 & 0.43 & 16.92 & 0.27 & -0.90 \\
\hline CIM-496 × Sindh-1 & 0.38 & -1.09 & -0.62 & 4.31 & 44.93 & -0.07 & -10.56 & 0.07 & 0.85 \\
\hline CIM-496 $\times$ BH-160 & -0.22 & 2.86 & 2.33 & -12.44 & 51.07 & -0.37 & -6.36 & -0.33 & 0.05 \\
\hline Sadori $\times$ Bt-cotton & 0.75 & 0.21 & 0.70 & -0.55 & 48.21 & 0.05 & -3.12 & -0.06 & 0.82 \\
\hline Sadori $\times$ Sindh -1 & -0.45 & -0.84 & -0.20 & -1.35 & 51.64 & 0.35 & 16.45 & 1.24 & -0.07 \\
\hline Sadori $\times \mathrm{BH}-160$ & -0.30 & 0.61 & -0.50 & 1.90 & 49.78 & -0.40 & -38.30 & -1.16 & 0.88 \\
\hline Chandi $\times$ Bt-cotton & -1.75 & 5.55 & 5.20 & 2.28 & 50.71 & 0.00 & 16.12 & 1.10 & 0.68 \\
\hline Chandi $\times$ Sindh -1 & 0.30 & -1.00 & -1.20 & -1.52 & 51.14 & -0.05 & -0.41 & -0.10 & -0.82 \\
\hline Chandi $\times$ BH-160 & 1.45 & 4.55 & -4.00 & -0.77 & 43.28 & 0.05 & -15.71 & -1.00 & 0.13 \\
\hline S.E. (si.) & 0.43 & 0.39 & 0.37 & 1.74 & 0.32 & 0.05 & 4.11 & 0.32 & 0.38 \\
\hline
\end{tabular}

DAP* $=$ days after planting. 
for almost all the traits indicating preponderance of additive genes controlling the traits. Jatoi et al. (2011) reported greater GCA than the SCA suggesting greater importance of additive against non-additive genes particularly dominant genes. It is generally believed that hybrid performance per se is most of the times but not always reflected in SCA effects (Baloch, 2004). However, in present studies, the results did not confirm it which indicates that, hybrid performance per se may not be trusted for their higher SCA effects (Jatoi et al., 2010). The mean performance of $\mathrm{F}_{1}$ hybrids per se is summarised in Table 2, indicat that CRIS-134 $\times$ Sindh-1 produced maximum bolls per plant, gave tallest plants, yet ranked next in GOT\% and staple length. While hybrid Sadori $\times$ Bt-cotton formed maximum bolls at 90 days after planting (DAP), yet ranked next good performing in bolls opened at 120 DAP, boll weight and seed cotton yield per plant. The hybrid Chandi $\times$ Bt-cotton opened maximum bolls at 120 DAP; CIM-496 $\times$ BT-cotton recorded bigger bolls; Sadori $\times$ Sindh-1 produced maximum seed cotton yield per plant and scored next in bolls per plant; CRIS-134 $\times$ BH-160 ginned maximum lint $\%$ and CRIS- $134 \times$ Bt-cotton measured longest staple. From these results it can be inferred that none of the $F_{1}$ hybrids was good performing for majority of the traits.

Among the female lines, Chandi formed lowest node to $1^{\text {st }}$ sympodial branch, opened maximum bolls at 120 DAP, whereas, Sadori formed maximum bolls at 90 DAP and measured tallest plants, weighed bigger bolls, produced maximum seed cotton yield and ginned highest GOT $\%$ and ranked second in bolls per plant and staple length; yet CRIS-134 set maximum bolls per plant and measured longest fibre length. These results suggested that earlier maturing variety may also form more number of total bolls hence, produce higher seed cotton yield (Jatoi et al., 2012).

Earliness is very important character in cotton because late maturing crop suffers from many losses like low market value, requires additional inputs, delays wheat sowing and favours late season insect-pest attacks (Jatoi et al., 2012). As far as GCA effects of lines are concerned, CRIS-134 displayed maximum GCA for number of bolls per plant, plant height, GOT \% and staple length; Sadori exhibited maximum GCA effects for bolls formed at 90 DAP, bolls opened at 120 (DAP) and seed cotton yield per plant; CIM-496 recorded higher GCA effects for boll weight and moderately desirable for plant height, yet CIM-506 expressed negative but desirable GCA effect for $1^{\text {st }}$ sympodial node number (Table 3). Parental lines CRIS-134 and Sadori, which exhibited higher GCA effects for seed cotton yield, its components and earliness characters may best be in hybridisation and selection programmes due to having additive genes. Khan et al. (2009), Mueen et al. (2008), Wu et al. (2008), and Zhu et al. (2007), noted significant GCA effects, which were due to additive genes for yield and earliness traits. $\mathrm{Lu}$ and Myers (2011) stated that, influential cotton lines are those, which contribute a larger proportion of genes to modern cotton cultivars than any other germplasm. From the tester parents, Sindh-1 demonstrated higher GCA effects for node number to set first sympodial branch, bolls formed at 90 DAP, bolls opened at 120 DAP and total bolls formed; Bt-cotton recorded maximum GCA effects for boll weight, seed cotton yield per plant and GOT \%, whereas, BH-160 for staple length, yet maximum negative but desirable GCA for node number to $1^{\text {st }}$ sympodial branch. Since the Pakistani breeders are very much interested in developing varieties, which are earlier in maturing and fit very well in wheatcotton rotation (Jatoi et al., 2012). In this context, parent Sindh-1 and Bt-cotton with additive genes may be potential parents for hybridisation and selection programmes so as to improve yield and earliness parameters simultaneously.

For hybrid crop to be feasible in cotton, it is very important to identify parents, which express high SCA effects. With respect to SCA effects, hybrid Sadori $\times$ Sindh-1 recorded maximum SCA for bolls per plant, boll weight, seed cotton yield per plant and GOT\%, whereas, Chandi $\times$ Bt-cotton exhibited maximum SCA for bolls formed at 90 DAP and bolls opened at 120 DAP, yet Sadori $\times$ BH-160 measured longer staple length and also gave negatively desirable SCA effects for $1^{\text {st }}$ sympodial node number. The hybrids, which manifested higher SCA effects are considered as having more dominant genes therefore can be potential crosses for hybrid cotton development. Yet for their commercial use, these hybrids could be evaluated for several years over multiple locations so as to confirm their superiority. Similar to present results, Patil et al. (2011) noted significant, SCA effects for seed cotton yield and fibre quality traits in cotton.

\section{Conclusion}

Combining ability estimates help plant breeders to select potential parents for hybridisation and selection programmes. The mean squares due to general combining ability (GCA) of lines and testers and specific 
combining ability (SCA) of lines $\times$ testers interactions were significant, indicating that both additive and nonadditive genes were advocating the characters. Among the lines, parents CIM-506, CRIS-134 and Sadori and from testers, Bt-cotton and Sindh-1 expressed higher GCA effects hence proved to be the best general combiners for most of the traits and are suitable parents for hybridisation and selection programmes. The $F_{1}$ hybrids like Sadori $\times$ Sindh-1, Chandi $\times$ Bt-cotton and Sadori $\times$ BH-160 were best specific combiners for earliness (bolls formation and opening at 90 and 120 days after planting), bolls per plant, boll weight, seed cotton yield per plant, lint $\%$ and staple length. The performance of $\mathrm{F}_{1}$ hybrids per se was very much reflected in SCA effects, conferring the potentiality of $\mathrm{F}_{1}$ hybrids.

\section{References}

Baloch, A.W., Baloch, M.J., Jatoi, W.A., Veesar, N.F. 2010. Production of superior $F_{1}$ hybrids:Genetic analysis for estimating combining ability in upland cotton (G.hirsutum L.). Journal of Agricultural Research, 48: 419-428.

Baloch, M.J. 2004. Genetic variability and heritability estimates of some polygenic traits in upland cotton. Pakistan Journal of Scientific and Industrial Research, 47: 451-454.

Baloch, M.J., Lakho, A.R., Bhutto, H.U., Memon, A.M., Panhwar, G.N., Soomro, A.H. 2000. Estimates of combining ability and genetic parameters for yield and fiber traits in upland cotton. Pakistan Journal of Biological Science, 3: 1183-1186.

Batool, S., Khan, N.U. 2012. Diallel studies and heritability estimates using Hayman's approach in upland cotton. SABRO Journal of Breeding and Genetics, 44: 322-338.

Batool, S., Khan, N.U., Makhdoom, K., Bibi, Z., Hassan, G., Marwat, K.B., Farhatullah, F., Mohammad, Raziuddin, Khan, I.A. 2010. Heritability and genetic potential of upland cotton genotypes for morphoyield traits. Pakistan Journal of Botany, 42: $1057-$ 1064.

Bhutto, H., Baloch, M.J., Yousaf, M. 2001. Diallel analysis for estimating combining ability of quantitatively inherited traits in upland cotton. Pakistan Journal of Biological Science, 1: 89-91.

Gomez, K.A., Gomez, A.A. 1984. Statistical Procedures for Agricultural Research, pp. 20-29, $2^{\text {nd }}$ edition, John Wiley \& Sons Inc., New York, USA.

Griffing, B. 1956. Concept of general and specific combining ability in relation to diallel analysis. Australian Journal of Biological Science, 9: 463-493.

Hassan, G., Mahmood, G., Khan, N.U., Razzaq, A. 1999. Combining ability and heterobeltiotic estimates in a diallel cross of cotton (Gossypium hirsutum L.). Sarhad Journal of Agriculture, 15: 563-568.

Jatoi, W.A., Baloch, M.J., Panhwar, A.Q., Veesar, N.F., Panhwar, S.A. 2012. Characterization and identification of early maturing upland cotton varieties. Sarhad Journal of Agriculture, 28: 53-56.

Jatoi, W.A., Baloch, M.J., Veesar, N.F., Panhwar, S.A. 2011. Combining ability estimates from line $\times$ tester analysis for yield and yield components in upland cotton genotypes. Journal of Agricultural Research, 49: 165-172.

Jatoi, W.A., Baloch, M. J., Khan, N.U., Veesar, N.F., Batool, S. 2010. Identification of potential parents and hybrids in intraspecific crosses of upland cotton. Sarhad Journal of Agriculture, 26: 25-30.

Kempthorne, O. 1957. An Introduction to Genetic Statistics, 545 pp., John Wiley, New York, USA.

Khan, M.A., Masood, A., Sadaqat, H.A., Cheema, K.L. 1991. Implication of combining ability and its utilization in cotton (Gossypium hirsutum L.). Journal of Agricultural Research, 29: 167-175.

Khan, S.A. 2010. Combining Ability Analysis in Upland Cotton (Gossypium hirsutum L.). M.Sc (Hons.) Thesis, Khyber Pakhtunkhwa Agriculture University, Peshawar, Pakistan.

Khan, N.U., Hassan, G., Kumbhar, M.B., Marwat, K.B., Khan, M.A., Parveen, A., Aiman, U., Saeed, M. 2009. Combining ability analysis to identify suitable parents for heterosis in seed cotton yield, its components and lint \% in upland cotton. Indus Crops Production, 29: 108-115.

Khan, N.U., Hassan, G., Kumbhar, M.B., Ghaloo, S.H. 2005. Combining ability analysis for morphological and yield traits in intra-hirsutum.L crosses. SAARC Journal of Agriculture, 3: 211-232.

Khan, N.U. 2003. Genetic Analysis, Combining Ability and Heterotic Studies for yield, its Components, Fiber and Oil Quality Traits in Upland Cotton (Gossypium hirsutum L.). Ph.D. Dissertation, Sindh Agriculture University, Tandojam, Pakistan.

Khanzada, S., Baloch, M.J., Soomro, Z.A., Kumbhar, M.B., Khan, N.U., Kumboh, N., Jatoi, W.A., Veesar, N.F. 2008. Estimating combining ability through line $\times$ tester analysis in upland cotton. Sarhad Journal of Agriculture, 24: 581-586. 
Lu, H., Myers, G.O. 2011. Combining abilities and inheritance of yield components in influential upland cotton varieties. Australian Journal of Crop Science, 5: 384-390.

Makhdoom, K. 2011. Combining Ability Estimates Through Line $\times$ Tester Analysis and Heritability in Upland Cotton. M.Sc (Hons.) Thesis, Khyber Pakhtunkhwa Agriculture University, Peshawar, Pakistan.

Makhdoom, K., Khan, N.U., Batool, S., Bibi, Z., Farhatullah, S. Khan, F. Mohammad, D., Hussain, Raziuddin, M. Sajjad, Khan, N. 2010. Genetic aptitude and correlation studies in Gossypium hirsutum L. Pakistan Journal of Botany, 42: 2011-2017.

Mueen, A.K., Moazzam, J., Muhammad, N., Irfan, A., Muhammad, S.K., Aamir, S. 2008. Heterosis in three intervarietal crosses for yield and yield contributing traits in cotton (Gossypium hirsutum L.). Journal of Applied Biosciences, 1: 13-17.

Panhwar, S.A., Baloch, M.J., Jatoi, W.A., Veesar, N.F., Majeedano, M.S. 2008. Combining ability estimates from line $\times$ tester mating design in upland cotton. Proceedings of Pakistan Academy of Sciences, 45: 69-74.

Patil, S.A., Naik, M.R., Patil, A.B. 2011. Line $\times$ tester analysis for seed cotton yield and fibre quality traits in (Gossypium hirsutum L). Plant Archives,
11: 525-528.

Sayal, O.U., Jatoi, S.A., Baloch, M.S., Hussain, I. 1997. Estimation of combining ability for quantitative traits in Gossypium hirsutum L. using Griffings technique of diallel. Scientific Khyber, 10: 13-21.

Singh, S., Singh, V.V., Choudhary, A.D. 2010. Combining ability estimates for oil content, yield components and fibre quality traits in cotton (Gossypium hirsutum L.) using an $8 \times 8$ diallel mating design. Journal of Tropical and Subtropical Agro-Ecosystems, 12: 161-166.

Singh, R.K., Choudhry, B.D. 1985. Biometrical Methods in Quantitative Genetic Analysis, pp. 205-214., $3^{\text {rd }}$ edition, Kalyani Publishers, New Dehli, India.

Sprague, F.F., Tatum, L.A. 1942. General versus specific combining ability in single crosses of corn. Journal of American Society, 34: 923.

Wu, Y.T., Yin, J.M., Guo, W.Z., Zhu, X.F., Zhang, T.Z. 2008. Heterosis performance of yield and fibre quality in $\mathrm{F}_{1}$ and $\mathrm{F}_{2}$ hybrids in upland cotton. Journal of Plant Breeding, 3: 285-289.

Zhu, C.X., Shu-xun, Y., Li-ping, G., Cheng-duo, M., Wen-juan, F., Hai-lin, W., Yun-lei, Z. 2007. Heterosis performance and correlation analysis on economic traits of upland cotton hybrids in different ecological environments. Journal of Cotton Science, 19: $3-7$ 